\title{
Biological Control of Fungal Strawberry Diseases by Serratia plymuthica HRO-C48
}

\author{
Stefan Kurze and Hubert Bahl, University of Rostock, Institute of Molecular Physiology and Biotechnology, \\ Microbiology, D-18051 Rostock, Germany; Robert Dahl, Strawberry Farm Rövershagen, Dorfstraße 2, D-18182 \\ Purkshof, Germany; and Gabriele Berg, University of Rostock, Institute of Molecular Physiology and Biotechnol- \\ ogy, Microbiology
}

\begin{abstract}
Kurze, S., Bahl, H., Dahl, R., and Berg, G. 2001. Biological control of fungal strawberry diseases by Serratia plymuthica HRO-C48. Plant Dis. 85:529-534.

To develop a biological control product for commercial strawberry production, the chitinolytic rhizobacterium Serratia plymuthica strain HRO-C48 was evaluated for plant growth promotion of strawberries and biological control of the fungal pathogens Verticillium dahliae and Phytophthora cactorum. In phytochamber experiments, treatment with S. plymuthica HRO-C48 resulted in a statistically significant enhancement of plant growth dependent on the concentration of the bacterium that was applied. In greenhouse trials, bacterial treatment reduced the percentage of Verticillium wilt (18.5\%) and Phytophthora root rot (33.4\%). In three consecutive vegetation periods, field trials were carried out in soil naturally infested by both soilborne pathogens on commercial strawberry farms located in various regions of Germany. Dipping plants in a suspension of $S$. plymuthica prior to planting reduced Verticillium wilt compared with the nontreated control by 0 to $37.7 \%$, with an average of $24.2 \%$, whereas the increase of yield ranged from 156 to $394 \%$, with an average of $296 \%$. Bacterial treatment reduced Phytophthora root rot by 1.3 to $17.9 \%$, with an average of $9.6 \%$, and increased strawberry yield by $60 \%$ compared with the nontreated control. Under field conditions, strain HRO-C48 survived at approximately $\log _{10} 3$ to $7 \mathrm{CFU} / \mathrm{g}$ of root in the strawberry rhizosphere at 14 months after root application. Although results of the field trials were influenced by pathogen inoculum density, cropping history of the field site, and weather conditions, S. plymuthica HRO-C48 successfully controlled wilt and root rot of strawberry.
\end{abstract}

Strawberry (Fragaria $\times$ ananassa Duch.) is an important high-value culturable crop. In recent years, an increase in strawberry production has been recorded worldwide (FAO, Statistical Databases). Verticillium wilt caused by Verticillium dahliae Kleb. and root rot caused by Phytophthora cactorum (Lebert \& Cohn) J. Schröt. are important diseases responsible for dramatic yield losses in commercial strawberry production (24). Microsclerotia of $V$. dahliae that develop in the senescing tissues of the dead plant may persist in soil for several years in the absence of a susceptible host; therefore, chemical control is nearly impossible (24). In the coming years, the loss of methyl bromide as a control measure for Verticillium wilt will have a great impact on the accumulation of microsclerotia in soil (13). Efficacious con-

Corresponding author: G. Berg

E-mail: gabriele.berg@biologie.uni-rostock.de

This research was supported by Grant 11393 from the Bundesministerium für Bildung, Wissenschaft, Forschung und Technologie $(b m b+f)$ and by the Fonds der Chemischen Industrie (Germany).

Accepted for publication 26 January 2001.

Publication no. D-2001-0305-02R

(C) 2001 The American Phytopathological Society trol methods are urgently needed for commercial strawberry production.

An environmentally friendly alternative to protect roots against fungal pathogens is rhizobacteria-mediated biological control $(7,12,34)$. Numerous studies have demonstrated the ability of several rhizobacteria to suppress diseases caused by fungal plant pathogens $(10,29,34,35)$. Isolates of the gram-negative bacterial genus Serratia are frequently found associated with plant roots and possess antifungal properties $(15,26,27)$. Therefore, they have potential for the biological control of plant pathogens. For example, Serratia liquefaciens from carnation rhizosphere is used to protect root cuttings (31), and S. marcescens B2 is able to control cyclamen soilborne diseases (32). S. plymuthica has been reported to exhibit antifungal effects against Fusarium culmorum, Pythium spp., and other fungal pathogens $(1,4,18,22)$.

S. plymuthica strain HRO-C48 was isolated from the rhizosphere of oilseed rape (18) and selected as a biocontrol agent according to the following criteria: (i) high chitinolytic activity responsible for activity against fungal pathogens (e.g., V. dahliae and Phytophthora cactorum) in vitro $(6,11,18)$; (ii) production of the plant growth hormone indole-3-acetic acid (18); (iii) relative harmlessness to human health and the environment (3); and (iv) low level of antibiotic resistance (5). The use of the antifungal properties of Serratia spp. for biocontrol of plant pathogens has been widely reported in scientific reports $(4,18,19,21,25)$ and also in patents $(8,20)$. It is surprising that no biocontrol product based on $S$. plymuthica is currently available on the market (see United States Department of Agriculture web site). Members of the species $S$. plymuthica were evaluated in only a few pathosystems (e.g., cucumber-Pythium ultimum; 25), and biocontrol results obtained under field conditions have never been reported.

The objective of our study was to evaluate $S$. plymuthica strain HRO-C48 for biocontrol of Verticillium wilt and Phytophthora root rot in strawberry. During three consecutive years, the efficacy of this biocontrol strain in phytochamber, greenhouse, and field trials on three different locations naturally infested by Verticillium or Phytophthora spp. was analyzed. The field trials were integrated into commercial strawberry production.

\section{MATERIALS AND METHODS}

Identification and culturing of bacteria and fungi. $S$. plymuthica was isolated from the rhizosphere of oilseed rape (18). A spontaneous mutant isolate of $S$. plymuthica resistant to rifampicin HROC48Rif (100 $\mu \mathrm{g} / \mathrm{ml}$; Fluka, Buchs, Switzerland) was used in all experiments. No differences in colony morphology, antifungal properties, and growth rate were found between the mutant and wild type. The strains of $S$. plymuthica were stored at $-70^{\circ} \mathrm{C}$ in nutrient broth (nutrient broth $2=$ $6.75 \mathrm{~g}$ of peptone, $5 \mathrm{~g}$ of $\mathrm{NaCl}, 1.5 \mathrm{~g}$ of yeast extract, $1.75 \mathrm{~g}$ of hydrolyzed protein in 1 liter of distilled water, $30^{\circ} \mathrm{C}, \mathrm{pH} 7.2$; Sifin, Berlin, Germany) containing 15\% glycerol. Identification using the API system (BioMérieux, Marcy l'Etoile, France) resulted in an identification rate of $57.5 \%$ (profile no. 1006323). With the Biolog system (BIOLOG Inc., Haward, CA), the strain was identified with an identification rate of $86.3 \%$. Additionally, the $16 \mathrm{~S}$ rRNA was sequenced and aligned with the reference 16S rRNA gene sequence using BLAST algorithm according to Altschul et al. (2). In comparison with the strain $S$. plymuthica PSM 4540 (EMBL Accession number AJ 2334331), strain HRO-C48 was determined to be S. plymuthica with $98 \%$ 
identity. The isolate was deposited in the German Collection of Microorganisms and Cell Cultures (Deutsche Sammlung für Mikroorganismen und Zellkulturen, Braunschweig, Germany) as DSMZ 12502. For greenhouse trials, the fungal strain Phytophthora cactorum PF-8 was obtained from the Federal Biological Research Center for Agriculture and Forestry (BBA, Darmstadt, Germany). The fungus was routinely grown on V8 juice agar at $16^{\circ} \mathrm{C}$ and stored in V8 juice broth with $15 \%$ glycerol at $-70^{\circ} \mathrm{C}$.

Phytochamber assay for effect of $S$. plymuthica on plant growth. Seeds of strawberry cv. Rügen Selecta (Erfurter Samenzucht, Erfurt, Germany) were pregerminated in moist chambers at $30^{\circ} \mathrm{C}$ for 6 days. Three standard 24-well microplates (Roth, Karlsruhe, Germany) were filled with $1 \mathrm{ml}$ of water agar containing $20 \mathrm{~g}$ of agar (Difco, Detroit, MI) made up to 1 liter with distilled water $(\mathrm{pH}$ 6.8). One pregerminated seed followed by $10 \mu \mathrm{l}$ of bacterial suspension (nutrient broth 2, grown for $18 \mathrm{~h}$ ) was added to each well. $S$. plymuthica was evaluated at $10^{3}, 10^{5}, 10^{7}$, and $10^{9} \mathrm{CFU} / \mathrm{ml}$ and compared with a control of $10 \mu \mathrm{l}$ of distilled water. Five weeks after incubation (16 h of artificial light, $22^{\circ} \mathrm{C}$ ) in a chamber (Percival Scientific, Boone, IA), first leaves and radial roots were counted to determine effects of bacterial treatment on plant growth. The strain was tested in six replicates at each concentration, and the experiment was repeated three times.

Biological control and growth promotion by $S$. plymuthica in the greenhouse. Soil naturally infested by $V$. dahliae (from the location in Stuthof, field trial I) or artificially infested by $P$. cactorum were used to evaluate biological control potential of S. plymuthica. Sterilized soil (sandy loam, $\mathrm{pH}$ 6.4) was infested with the pathogenic fungus $P$. cactorum PF-8 according to Hessenmüller and Zeller (17). Mycel plugs of $P$. cactorum PF-8 were inoculated in a 4liter mixture of wheat bran:vermiculite (1:1) containing $240 \mathrm{~g}$ of soybean flour and $668 \mathrm{ml}$ of distilled water. This mixture was incubated for 28 days at $22^{\circ} \mathrm{C}$. Polypropylene boxes (0.7-liter) were filled with soil and Phytophthora inoculum (4\%) and planted with strawberry frigo cv. Elsanta plants (Janssen, Kalkar, Germany). Prior to planting, the roots were dipped in a suspension of S. plymuthica $\left(2 \times 10^{9} \mathrm{CFU} / \mathrm{ml}\right)$ for $15 \mathrm{~min}$. The nontreated control plants were dipped in tap water and planted in infested soil. A negative control using pathogen-free soil was included in each test. Ten replicates of each treatment were performed in a completely randomized block design. All treatment combinations were repeated three times. The experiments were conducted under greenhouse conditions (18 h of light, sodium lamps, $100 \mathrm{mE} / \mathrm{m}^{2} / \mathrm{s}, 25 \pm 1{ }^{\circ} \mathrm{C}$ ) over a 10 -week period. After inoculation, disease incidence based on a 0 -to- 2 scale, with $0=$ no disease, $1=$ infected plant showing wilting symptoms, and $2=$ dead plants, was recorded and the number of buds and blossoms were counted. To evaluate the influence of the treatment on yield, the weights of fruit were measured. At the end of the 10-week trial, plant roots with adhering soil taken from five plants per treatment were aseptically sampled to sterile Stomacher bags. Each sample (5 g) was extracted in a Stomacher laboratory blender (BagMixer, Interscience, St. Nom, France) with sterile $\mathrm{NaCl}$ solution (8.5 g per liter). Solutions were serially diluted and plated on nutrient agar 2 containing rifampicin (Fluka) at $100 \mu \mathrm{g} / \mathrm{ml}$. CFU were determined after a 5-day incubation at $20^{\circ} \mathrm{C}$. The total culturable bacterial populations in the rhizosphere were determined using the same procedure on nutrient agar.

Biological control of Verticillium wilt and Phytophora root rot in field trials. Field trials I (1997, location Stuthof) and II (1998, location Goorstorf) were conducted in Mecklenburg-Western-Pomerania, Germany, in areas naturally infested by $V$. dahliae. Soil population density of $V$. dahliae in Stuthof and Goorstorf was 40 and $21 \mathrm{microsclerotia/g}$ of soil, respectively, determined by Termorshuizen's soil dilution method (33). In 1999, field trial III was carried out in Bühl, Baden-Württemberg, in a field naturally infested by $P$. cactorum at 1,000 CFU/g of soil (17). Soil parameters at all locations were analyzed by the Institute for Agricultural Analysis and Research (LUFA, Rostock or Bonn, Germany). In Stuthof (trial I), the soil texture was loamy sand, pH 5.5, 1.7\% organic matter, with the following nutrients in milligrams per $100 \mathrm{~g}$ of soil: $\mathrm{P}_{2} \mathrm{O}_{5}, 12$; $\mathrm{K}_{2} \mathrm{O}, 15$; and $\mathrm{Mg}$, 6. In Goorstorf (trial II), the soil texture was sand, $\mathrm{pH} 5.7,1.3 \%$ organic matter, with the following nutrients in milligrams per $100 \mathrm{~g}$ of soil: $\mathrm{P}_{2} \mathrm{O}_{5}, 16$; $\mathrm{K}_{2} \mathrm{O}, 8$; and $\mathrm{Mg}$, 11. In Bühl (trial III), the soil texture was sandy loam, $\mathrm{pH} 5.1$, with the following nutrients in milligrams per 100 g of soil: $\mathrm{P}_{2} \mathrm{O}_{5}, 24 ; \mathrm{K}_{2} \mathrm{O}, 33$; and $\mathrm{Mg}$, 5. In trials I and II, approximately 1,200 strawberry cv. Elsanta plants were grown in a completely randomized block design with six replicates. The strawberries were planted as frigo plants in May, harvested as runner plants in autumn, and stored at $-2^{\circ} \mathrm{C}$ during the winter. In trial III, approximately 100 strawberry cv. Elsanta plants per treatment were grown in a completely randomized block design with four replicates. The roots of strawberry plants were dipped in a bacterial suspension $(4 \times$ $\left.10^{9} \mathrm{CFU} / \mathrm{ml}\right)$ immediately prior to planting. Controls were dipped in tap water. In July of the same year, the strawberry fruits were harvested and weighed to determine yield and the percentage of wilted and dead plants was monitored. In field trial III, the strawberries were planted as runner plants in August and treated with S. plymuthica as described above. Disease incidence (based on a 0 -to- 2 scale, with $0=$ no disease, $1=$ infected plant showing wilting symptoms, and 2 = dead plants) was recorded in September and October of 1999. At four different sampling times (young plants, flowering plants, fruiting plants, and flowering plants in the second year after planting), plant roots with adhering soil taken from five plants from one treatment were aseptically sampled to sterile Stomacher bags and treated as one sample. Five replicates for each treatment were investigated. Each sample $(5 \mathrm{~g})$ was extracted in a Stomacher laboratory blender (BagMixer) with sterile $\mathrm{NaCl}$ solution (8.5 g per liter). Solutions were serially diluted and plated on nutrient agar 2 containing rifampicin at $100 \mathrm{ppm}$ (Fluka). CFU were determined after a 5day incubation at $20^{\circ} \mathrm{C}$. The total culturable bacterial populations in the rhizosphere was determined using the same procedure on nutrient agar. Weather data were obtained from the State Agency of Environment, Nature Conversation, and Geology, Mecklenburg-Western-Pomerania (LUNG, Güstrow, Germany) and the Deutscher Wetterdienst (Offenbach, Germany).

Statistical analysis. Data on the percentages of disease incidence and yield were analyzed for significance using UTest "Mann-Whitney" $(P \leq 0.05)$ by Statistical Product and Service Solutions for Windows, Rel. 9.0.1. (SSPS Inc., Chicago). Root colonization data were $\log _{10}$ transformed before statistical analysis. A polynomic regression analysis was used to compare the treatments at each S. plymuthica concentration in the phytochamber assay.

\section{RESULTS}

Plant growth promotion in phytochamber. The effect of $S$. plymuthica on plant growth was dependent on the bacterial population applied on germ buds (Fig. 1). Germ buds treated with a bacterial population at a concentration of $10^{3}$ $\mathrm{CFU} / \mathrm{ml}$ had more first leaves $(P=0.000)$ and radial roots $(P=0.009)$ compared with the nontreated control. The plant growth promotion effect was also shown at higher bacterial concentrations $\left(10^{5} \mathrm{CFU} / \mathrm{ml}\right.$ : leaves $[P=0.000]$ and roots $[P=0.002]$; $10^{7} \mathrm{CFU} / \mathrm{ml}$ : leaves $[P=0.006]$ and roots $[P=0.095])$. At bacterial populations $>10^{7}$ $\mathrm{CFU} / \mathrm{ml}$, the percentage of leaves and radial roots was not different from the nontreated control. The dose effect for the increase of leaves was significant. Significant differences in the increase of leaves were found between the $S$. plymuthica concentrations applied.

Effects of $S$. plymuthica HRO-C48 on disease incidence and strawberry growth and yield under greenhouse conditions. In soil naturally infested by $V$. dahliae (greenhouse trial I) and artificially inoculated by $P$. cactorum (greenhouse trial II), treating plants with $S$. plymuthica re- 
duced the number of wilted and necrotized plants (Table 1). Ten weeks after treatment, the average reduction of Verticillium wilt was $8.2 \%$ and the reduction of Phytophthora root rot was $3.6 \%$ compared with the nontreated control. Plants treated with S. plymuthica and planted in soils infested by $V$. dahliae or P. cactorum had 33.2 and $16.2 \%$ more buds and blossoms, respectively, than the nontreated control. In the nontreated controls of both trials, the initiation of flowering was delayed. In both trials, yield was increased by treatment with S. plymuthica (Table 1). Yield was increased by $18.5 \%$ in soil naturally infested by Verticillium spp. and, in soils infested with $P$. cactorum, yield was increased by $33.4 \%$.

After 10 weeks, the population of $S$. plymuthica HRO-C48 and the total bacterial populations in the strawberry rhizosphere were determined. S. plymuthica strain HRO-C48 colonized the treated roots of strawberry at population densities between 5.4 and $6.6 \log _{10}$ CFU/g of root. $S$. plymuthica was not detected in the nontreated control rhizospheres. The total bacterial populations in the rhizosphere ranged from 6.2 to $7.1 \log _{10} \mathrm{CFU} / \mathrm{g}$ of root and were not different among treatments.

Effect of $S$. plymuthica HRO-C48 on disease incidence and strawberry growth and yield in field trials. Three field trials at different locations were carried out to evaluate the ability of $S$. plymuthica HROC48 to suppress the pathogens under natural conditions. In field trial I (1997, Stuthof), wilting symptoms of $V$. dahliae were reduced (0 to 37.7\%) in plots treated with strain S. plymuthica (92 diseased plants to 235 healthy plants) compared with nontreated control plots (203 diseased plants to 190 healthy plants) (Fig. 2). In field trial II (1998, Goorstorf), symptoms of $V$. dahliae did not develop. Differences in disease incidence between the control and $S$. plymuthica HRO-C48-treated plants were not detected. In field trial III, the reduction of Phytophthora root rot by the treatment with S. plymuthica compared with the nontreated control ranged from 1.3 to $17.9 \%$, with an average of $9.6 \%$ (Fig. 2). In field trial I (1997), the yield of strawberries in plants treated with $S$. plymuthica $(32.5 \mathrm{~kg}$ per 100 plants) was $296 \%$ greater than in the nontreated control ( $8.2 \mathrm{~kg}$ per 100 plants). In field trial II (1998, Goorstorf), yield was not different between the control and plants treated with $S$. plymuthica. In field trial III, plants treated with $S$. plymuthica exhibited greater growth 1 month after planting in September and in October.

S. plymuthica HRO-C48 was reisolated throughout the 14-month period (Fig. 3) and identified using the API and BIOLOG systems. In field trial I, S. plymuthica was recovered at the second (flowering plants) and third (fruiting plants) sampling periods. For both field trials I (1997, Stuthof) and II (1998, Goorstorf), S. plymuthica
HRO-C48Rif decreased each period. Fourteen months after planting, S. plymuthica was detected at significantly lower levels $\left(\log _{10} 2.9 \mathrm{CFU} / \mathrm{g}\right.$ of root in Stuthof in 1998 [field trial I]). In 1999, 2 years after inoculation, the strain was not recovered from the soil in Goorstorf (field trial
II). In the field trials, the total bacterial populations were investigated to monitor the influence of the introduced strain on the bacterial community. Total bacterial populations recovered from the rhizospheres treated with $S$. plymuthica were similar to the nontreated control.

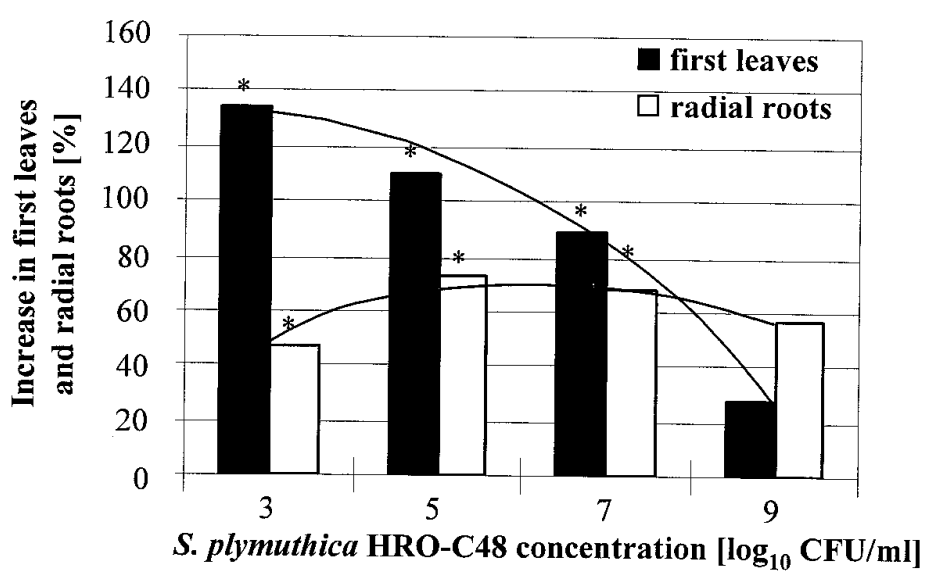

Fig. 1. Influence of different concentrations of Serratia plymuthica strain HRO-C48; 3 weeks after treatment on the development of strawberry first leaves and radial roots compared with a nontreated control in a phytochamber assay. A suspension of $S$. plymuthica $(10 \mu \mathrm{l})$ at concentrations of $10^{3}, 10^{5}$, $10^{7}$, and $10^{9} \mathrm{CFU} / \mathrm{ml}$ was applied on each of the 72 seeds per treatment. Significant differences $(P \leq$ 0.05 ) were determined by Mann-Whitney and are indicated by asterisks.

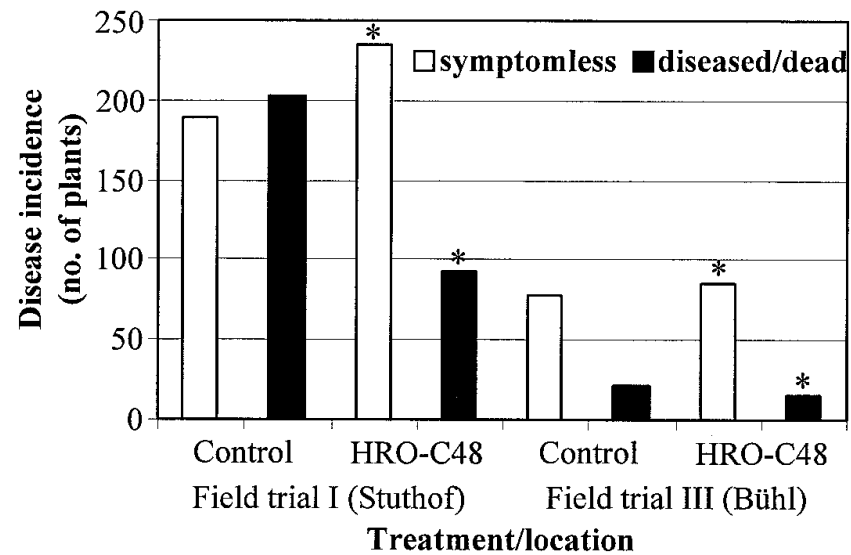

Fig. 2. Numbers of symptomless and diseased or dead plants treated with Serratia plymuthica strain HRO-C48 compared with a nontreated control in randomized field trials $(I=1997$, Stuthof; II = 1998, Goorstorf; and III = 1999, Bühl). S. plymuthica strain HRO-C48 was applied by dipping the roots in a suspension $\left(4 \times 10^{9} \mathrm{CFU} / \mathrm{ml}\right)$ immediately prior to planting. Disease symptoms were monitored in September, 1 month after harvest (fields I and II) or 1 month after planting (field trial III). Significant differences $(P \leq 0.05)$ were determined by Mann-Whitney and are indicated by asterisks.

Table 1. Effect of Serratia plymuthica strain HRO-C48 on disease incidence and strawberry growth (numbers of buds and blossoms) and yield in greenhouse trials using soil naturally infested by Verticillium dahliae or artificially infested by Phytophthora cactorum $^{\mathrm{a}}$

\begin{tabular}{lccr}
\hline Trial no., treatment & Disease incidence (SE) & No. of buds and blossoms (SE) & Yield (SE) \\
\hline I & & & \\
$\quad$ Negative control & $0( \pm 0.044)$ & $3.1( \pm 2.2)$ & $11.6( \pm 0.5)$ \\
Nontreated control & $0.926( \pm 0.09)$ & $0.76( \pm 1.1)$ & $5.1( \pm 1.1)$ \\
HRO-C48-treatment & $0.76( \pm 0.082)$ & $1.79( \pm 1.9)$ & $7.2( \pm 1.8)$ \\
II & & $3.1( \pm 2.2)$ & $11.6( \pm 0.5)$ \\
Negative control & $0( \pm 0.044)$ & $0.67( \pm 1.2)$ & $1.7( \pm 1.5)$ \\
Nontreated control & $0.562( \pm 0.08)$ & $3.03( \pm 2.1)$ & $5.6( \pm 0.7)$ \\
HRO-C48-treatment & $0.49( \pm 0.084)$ &
\end{tabular}

${ }^{a}$ Disease incidence, number of buds and blossoms, and yield $(\mathrm{g}) \pm$ standard error (SE). 
Climatic aspects. Weather conditions during field trials I (1997), II (1998), and III (1999) were different (Fig. 4). The vegetation period in 1997 started with a cold and rainy spring (May: temperature $=$ $10.8^{\circ} \mathrm{C}$, rainfall $=2.4 \mathrm{~mm}$ ) during planting. This period was followed by a warm, dry summer with a maximum temperature of $21^{\circ} \mathrm{C}$ in August and low rainfall $(1.9 \mathrm{~mm})$ during the flowering period and harvest. In contrast, the spring of 1998 was not as cold as the spring of 1997 (May $=12.9^{\circ} \mathrm{C}$ ) and the total rainfall level was lower $(1.4 \mathrm{~mm})$. In 1998, during the flowering period and harvest, the temperature between June and October was generally lower $\left(13.9^{\circ} \mathrm{C}\right.$ on average) compared with $1997\left(15.4^{\circ} \mathrm{C}\right)$. The amount of rainfall from June to October was higher than the year before. After harvest at the end of October, the conditions in both years (1997 and 1998) were similar, with an average temperature of $8.7^{\circ} \mathrm{C}$ day $^{-1}$. The level of rainfall per month ranged from 1.4 to $1.9 \mathrm{~mm}$. The third trial, located in Bühl (Baden-Württemberg), had higher average temperatures and rainfall per month than the other trails.

\section{DISCUSSION}

Potential use of root-colonizing bacteria as replacements or supplements for chemical fungicides have been addressed in many reports $(10,29,34,35)$. In the present study, the potential of a strain of $S$. plymuthica isolated from the rhizosphere of oilseed rape for controlling Verticillium wilt and Phytophthora root rot of strawberries in greenhouse and field trials was evaluated over a 3-year period.

A requirement for an efficient biological control agent is the ability to survive and to become established in the rhizosphere (23).

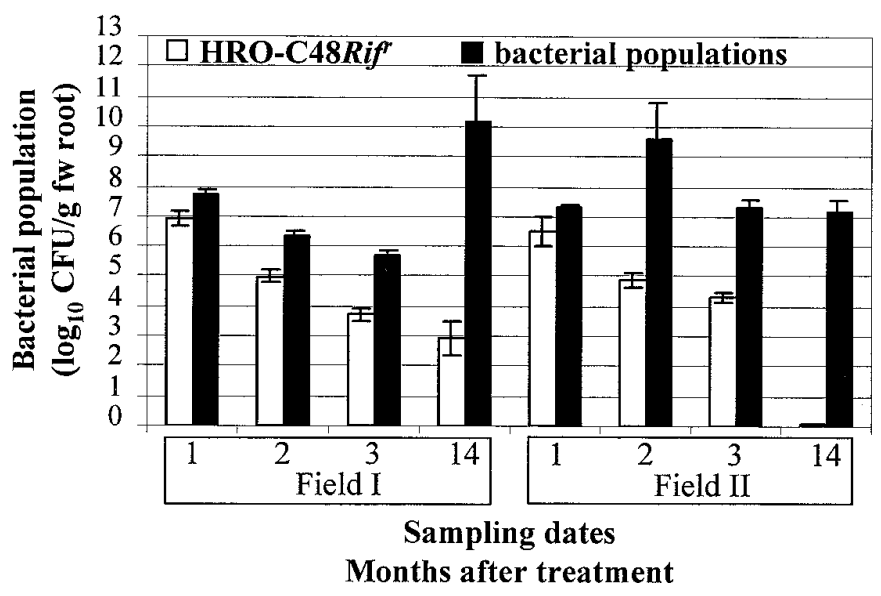

Fig. 3. Mean bacterial plate counts from the rhizosphere of field trial I (Stuthof, 1997 and 1998) and field trial II (Goorstorf, 1998 and 1999). Rhizosphere population densities of the rifampicincontaining agar (nutrient agar, $100 \mu \mathrm{g} / \mathrm{ml}$ of rifampicin) reisolated strain HRO-C48Rif ${ }^{\text {(spontaneous }}$ rifampicin resistant mutant) and bacterial populations (CFU on nutrient agar) were determined as $\log _{10}$ CFU per gram of root fresh weight (fw root). Populations at each sampling time (1: young plants, 2: flowering plants, 3: fruiting plants, 4: flowering plants in the second year of harvest) represent the average bacterial population densities of six replicates in Stuthof and three replicates in Goorstorf. Significant differences $(P \leq 0.05)$ were determined by Mann-Whitney and are indicated by bars.

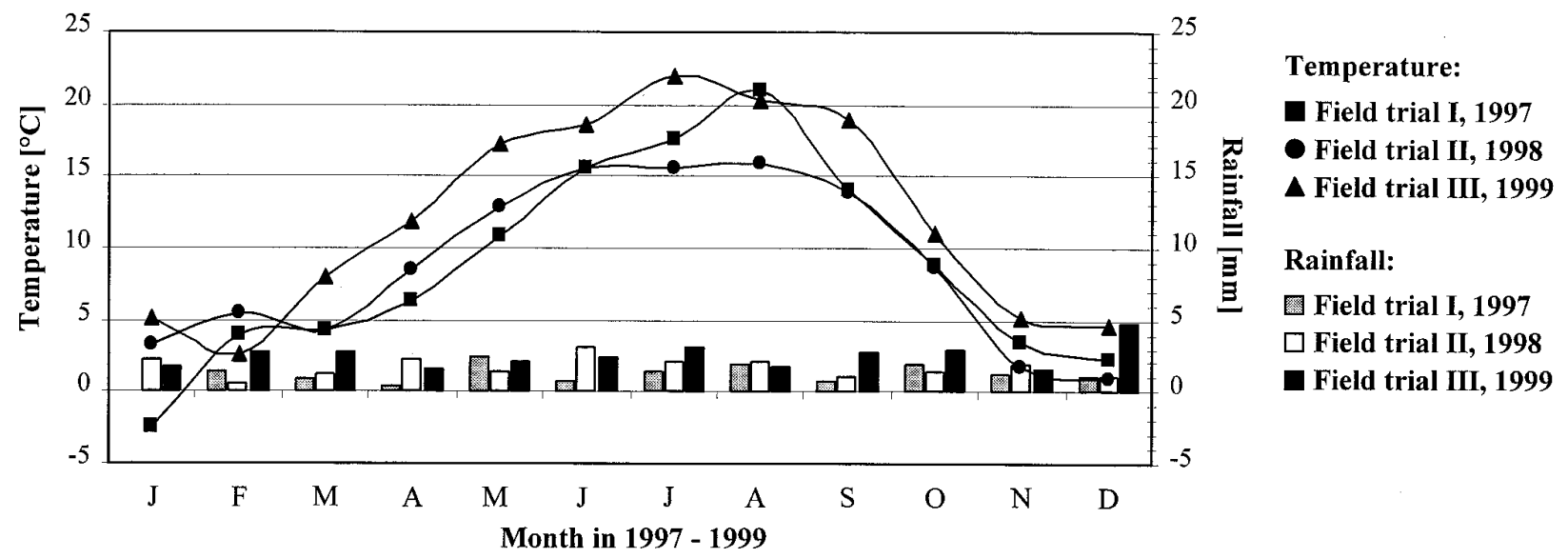

Fig. 4. Monthly mean air temperature $\left({ }^{\circ} \mathrm{C}\right)$ and total rainfall for field trial I (1997, Stuthof), field trial II (1998, Goorstorf), and field trial III (1999, Bühl). 
soil have been demonstrated to infect the susceptible strawberry cv. Elsanta under optimal conditions for an infection of the fungus (16). The cropping history of a site is also a good indicator of wilt risk (16). Plants that increase the soil inoculum of $V$. dahliae, such as potato, cotton, brassica crops, sugar beet, and miscellaneous vegetables, enhance the potential risk of infection. Field trial I was planted after oilseed rape, a host of $V$. dahliae which was responsible for the high inoculum level of $V$. dahliae (36). In contrast, field trial II was planted on a field formerly used for barley, a plant that does not host Verticillium spp. Weather conditions also had an influence on the field trials. For example, the infection data of field trial I reflect the fact that years with a warm, dry summer are known to favor wilt in strawberry. Soil parameters (sand, nutrients) in the different trials were very similar and we do not consider them a factor.

The plant growth promoting ability of $S$. plymuthica was observed in phytochambers and was confirmed in greenhouse and field trials. Treatment with S. plymuthica resulted in an increase of the number of buds, blossoms, and fruit. In addition, intense root branching for plants treated with S. plymuthica HRO-C48 was observed in the greenhouse and field trials (data not shown). The in vitro test in phytochambers is an easy and fast assay to test the plant growth-promoting potential and is ideal to screen a large number of isolates. The greenhouse trials using soil artificially and naturally infested by $S$. plymuthica are suitable to check the efficacy under defined abiotic and biotic conditions. However, the success of biological approaches to control plant diseases must ultimately be judged by their performance under field conditions. In our field trials, S. plymuthica HRO-C48 showed efficacy in controlling wilt and root rot of strawberry caused by $V$. dahliae and P. cactorum.

In this study, the strategy for effective selection and evaluation of a potent biocontrol agent was successful. On the basis of the presented results, it was possible to patent $S$. plymuthica HRO-C48 as a biological control agent (8). The results described here are promising for commercial application of S. plymuthica strain HROC48. The development of a commercial formulation of S. plymuthica HRO-C48 is in progress and, in the near future, RhizoStar will be commercially available from PROPHYTA GmbH (Malchow/Poel, Germany). Artificial inoculation with $S$. plymuthica offers a possibility for controlling Verticillium wilt and Phytophthora root rot that can be integrated into the agricultural production process and is sustainable and environmentally friendly.

\section{ACKNOWLEDGMENTS}

We thank W. Zeller and M. K. Gulati (Federal Biological Research Center for Agriculture and
Forestry, Darmstadt, Germany) for evaluating the strain Serratia plymuthica HRO-C48 in their field trial; the $H$. von Mansberg strawberry farm, Rövershagen, for their excellent cooperation; $\mathrm{H}$. Goschke, N. Sauerbrunn, and D. Marquardt for valuable technical and practical assistance; and A. Minkwitz for sequencing the 16S rRNA of $S$. plymuthica HRO-C48.

\section{LITERATURE CITED}

1. Alström, B., and Gerhardson, B. 1988. Differential reactions of wheat and pea genotypes to root inoculation with growth-affecting rhizobacteria. Plant Soil 109:263-269.

2. Altschul, S. F., Madden, T. L., Schaffer, A. A., Zhang, J., Miller, W., and Lipman, D. J. 1997. Gapped BLAST and PSI-BLAST: a new generation of protein database search programs. Nucleic Acids Res. 25:3389-3402.

3. Anonymous. 1990. Berufsgenossenschaft der chemischen Industrie: Sichere Biotechnologie. Einstufung biologischer Agenzien: Bakterien: Merkblatt B 006. Jedermann-Verlag Heidelberg, Germany.

4. Benhamou, N., Gagné, S., Le Quéré, D., and Dehbi, L. 2000. Bacterial-mediated induced resistance in cucumber: Beneficial effect of the endophytic bacterium Serratia plymuthica on the protection against infection by Pythium ultimum. Phytopathology 90:45-56.

5. Berg, G. 2000. Diversity of antifungal and plant-associated Serratia plymuthica strains. J. Appl. Microbiol. 88:952-960.

6. Berg, G., Frankowski, J., and Bahl, H. 2000. Interactions between Serratia plymuthica and the soilborne pathogen Verticillium longisporum. Pages 269-273 in: Advances in Verticillium Research and Disease Management. E. C. Tjamos, R. Rowe, J. B. Heale, and D. R. Fravel, eds. APS Press, St. Paul, MN

7. Berg, G., Knaape, C., Ballin, G., and Seidel, D. 1994. Biological control of Verticillium dahliae KLEB. by naturally occuring rhizosphere bacteria. Arch. Phytopathol. Dis. Prot. 29: 249-262.

8. Berg, G., Kurze, S., and Dahl, R. 1999. Rhizobacterial isolates for use against phytopathogenic soil fungi and process for applying these rhizobacterial isolates. Europäisches Patent Nr. 98124694.5, US-Patent 2662-001 US-1.

9. Bletsos, F. A., Thanassoulopoullos, C. C., and Roupankas, D. G. 1999. Water stress and Verticillium wilt severity on eggplant (Solanum melongena L.) J. Phytopathol. 147:243-248.

10. Emmert, E. A. B., and Handelsman, J. 1999. Biocontrol of plant disease: a $\left(\mathrm{Gram}^{-}\right)$positive perspective. FEMS Microbiol. Lett. 171:1-9.

11. Frankowski, J., Berg, G., and Bahl, H. 1998. Mechanisms involved in the antifungal interactivity of the rhizobacterium Serratia plymuthica. IOBC Bull. 21: 45-50.

12. Fravel, D. R. 1992. Systems for efficient delivery of microbial biocontrol agents to soil. Pages 399-406 in: Biological Control of Plant Diseases. Progress and Challenges for the Future. NATO ASI Series, Series A, Vol. 230. E. C. Tjamos, G. C. Papavizas, and R. J. Cook, eds. Plenum Press, New York.

13. Fravel, D. R., and Larkin, R. P. 1996. Availability and application of biocontrol products. Biol. Cult. Tests Control Plant Dis. 11:1-7.

14. Green, R. J. 1980. Soil factors affecting survival of microsclerotia of Verticillium dahliae. Phytopathology 70:353-5.

15. Grimont, F., and Grimont, P. A. D. 1992. The genus Serratia. Pages 2823-2848 in: The Prokaryotes-A Handbook on the Biology of Bacteria: Ecophysiology, Isolation, Identification, Applications. Second Edition. Vol. III. A. Balows, H. G. Trüper, M. Dworkin, W. Harder, and K. H. Schleifer, eds. Spinger
Verlag, New York.

16. Harris., D. C., and Yang, J. R. 1996. The relationship between the amount of Verticillium dahliae in soil and the incidence of strawberry wilt as a basis for disease risk prediction. Plant Pathol. 45:106-114.

17. Hessenmüller, A., and Zeller, W. 1996. Biologische Bekämpfung von bodenbürtigen Phy tophtora Arten an der Erdbeere. J. Plant Dis. Prot. 103:602-609.

18. Kalbe, C., Marten, P., and Berg, G. 1996. Members of the genus Serratia as beneficial rhizobacteria of oilseed rape. Microbiol. Res. 151:433-439.

19. Kloepper, J. W., Wei, G., and Tzun, S. 1992. Rhizosphere population dynamics and internal colonization of cucumber by plant growth-promoting rhizobacteria, which induce systemic resistance to Colletotrichum orbiculare. Pages 185-192 in: Biological Control of Plant Diseases. Progress and Challenges for the Future. NATO ASI Series, Series A, Vol. 230. E. C. Tjamos, G. C. Papavizas, and R. J. Cook, eds. Plenum Press, New York.

20. Leifert, C., Epton, H. A. S., and Sigee, D. C. 1997. Antibiotics for biological control of post harvest diseases. US-Patent 5,597,565.

21. Lievens, K. H., Van Rijsbergen, R., Leyns, F. R., Lambert, B. J., Tenning, P., Swings, J., and Joos, H. J.-P. 1989. Dominant rhizosphere bacteria as a source for antifungal agents. Pestic. Sci. 27:141-154.

22. Lottmann, J., Heuer, H., Smalla, K., and G. Berg. 1999. Influence of transgenic T4-lysozyme-producing plants on beneficial plantassociated bacteria. FEMS Microbiol. Ecol. 29:365-377.

23. Lugtenberg, B. J. J., and Dekkers, L. C. 1999. What makes Pseudomonas bacteria rhizosphere competent? Environ. Microbiol. 1:913.

24. Maas, J. L. 1998. Compendium of Strawberry Diseases. APS Press, St. Paul, MN.

25. McCullagh, M., Utkehde, R., Menzies, J. G., Punja, Z. K., and Paulitz, T. C. 1996. Evaluation of plant growth-promoting rhizobacteria for biological control of Pythium root rot of cucumbers grown in rockwool and effects on yield. Eur. J. Plant Pathol. 102:747-755.

26. McInroy, J. A., and Kloepper, J. W. 1994. Studies on indigenous endophytic bacteria of sweet corn and cotton. Pages 19-28 in: Molecular Ecology of Rhizosphere Microorganisms. O'Gara, F. O., Dowling, D. N., and B. Boeston, eds. VCH, Weinheim, Germany.

27. McInroy, J. A., and Kloepper, J. W. 1995. Survey of indigenous bacterial endophytes from cotton and sweet corn. Plant Soil 173:337-342.

28. McKinley, R. T., and Talboys, P. W. 1979. Effects of Pratylechus penetrans on development of strawberry wilt caused by Verticillium dahliae. Ann. Appl. Biol. 92:347-357.

29. O'Sullivan, D. J., and O'Gara, F. 1992. Traits of fluorescent Pseudomonas spp. involved in suppression of plant root pathogens. Microbiol. Rev. 56:662-676.

30. Scher, F. M., Ziegle, J. S., and Kloepper, J. W. 1994. A method for assessing the root-colonizing capacity of bacteria on maize. Can. J. Microbiol. 30:151-157.

31. Sneh, B., Agamis, O., and Baker, R. 1985. Biological control of Fusarium wilt in carnation with Serratia liquefaciens and Hafnia alvei isolated from rhizosphere of carnation. J. Phytopathol. 113:271-276.

32. Someya, N., Kataoka, N., Komagata, T., Hirayae, K., Hibi. T., and Akutsu, K. 2000 Biological control of cyclamen soilborne diseases by Serratia marcescens. Plant Dis. 84:334-340. 
33. Termorshuizen, A. J., Davis, J. R., Gort, G., Harris, D. C., Huisman, O. C., Lazarovits, G., Locke, T., Melero Vara, J. M., Mol, L., Paplomatas, E. J., Platt, H. W., Powelson, M., Rouse, D. I., Rowe, R. C., and Tsror, L. 1998. Interlaboratory comparison of methods to quantify microsclerotia of Verticillium dahliae in soil. Appl. Environ. Microbiol. 64:3846-
3853.

34. Weller, D. M. 1988. Biological control of soilborne plant pathogens in the rhizosphere with bacteria. Annu. Rev. Phytopathol. 26:379-407.

35. Whipps, J. M. 1997. Ecological considerations involved in commercial development of biological control agents for soilborne dis- eases. Pages 525-545 in: Modern Soil Microbiology. J. D. Van Elsas, J. T. Trevors, and E. M. H. Wellington, eds. Marcel Dekker, Inc., New York.

36. Zeise, K., Seidel, D., and Amelung, D. 1990. Zum Befallsverlauf von Verticillium dahliae an Winterraps. Arch. Phytopathol. Pflanzenschutz 26:205-206. 